\title{
Comparative human resource management
}

Book or Report Section

Accepted Version

Brewster, C. and Haak-Saheem, W. (2020) Comparative human resource management. In: Darwish, T. K. and Muda Abdul Fattaah, P. (eds.) Human Resource Management in an Emerging South Asian Economy: The Case of Brunei. Routledge Studies in Human Resource Development. Routledge, New York, USA. ISBN 9780429030963 doi: https://doi.org/10.4324/9780429030963 Available at https://centaur.reading.ac.uk/87463/

It is advisable to refer to the publisher's version if you intend to cite from the work. See Guidance on citing.

To link to this article DOI: http://dx.doi.org/10.4324/9780429030963

Publisher: Routledge

All outputs in CentAUR are protected by Intellectual Property Rights law, including copyright law. Copyright and IPR is retained by the creators or other copyright holders. Terms and conditions for use of this material are defined in the End User Agreement.

\section{www.reading.ac.uk/centaur}




\section{CentAUR}

Central Archive at the University of Reading

Reading's research outputs online 


\title{
CHAPTER THREE
}

\section{Comparative Human Resource Management}

\author{
Chris Brewster and Washika Haak-Saheem
}

\begin{abstract}
This chapter focuses on comparative human resource management (HRM). It explores the differences between nations in the way that they manage their human resources. Within a context of increasing globalisation, the chapter highlights how context matters to HRM. Fundamental to understanding these differences between countries are two concepts: the notions of cultural and institutional differences, and the notions of convergence and divergence. The chapter contributes to a better understanding of the main concepts and theories relevant to comparative HRM. First, this chapter shows that cultural and institutional explanations are valuable to the comparative HRM approach. Further, it argues that convergence of trends is apparent, but final convergence remains unrealistic. Finally, it outlines some of the key theoretical, empirical and practical challenges posed by a comparative approach to HRM.
\end{abstract}

\section{Introduction}

This chapter explores the differences between the way that countries manage their human resources. Despite the growing process of globalisation, the chapter argues that context still matters. Further, we explain how different countries have different notions of 'HRM' and what it means, how it is understood, and what would be considered effective HRM policies and practices. These differences present a challenge to multinational enterprises (MNEs) managing workers in 
different countries (see chapter on international human resource management (IHRM)). And significantly, comparative HRM is a challenge to the universalist paradigm of HRM, generally expressed in the notion of best practice. Given the comparative lens, comparative HRM argues that the subject has to be seen within its contextual setting, including both the internal context, such as leadership style, level or organisation, and the external environment, such as the national culture or national institutional factors.

Context is a critical factor influencing management in general (Bamberger, 2008) and HRM in particular (Cooke, 2018). It is argued that the outcomes of HRM should be measured via its longterm effects on organisational effectiveness, and individual and societal well-being (Beer, Boselie, \& Brewster, 2015). These long-term effects have been ignored in the universalist approach to strategic human resource management (SHRM). Scholars and practitioners must develop a solid understanding of the specifications of the contextual environment in order to foster HRM practices that are sustainable and of benefit for all stakeholders. In addition to the strong interest of comparative HRM in how HRM in different countries emerges over time, it is of relevance to examine whether existing HRM practices evolve towards a common model.

The globalisation, or convergence, debate is a fundamental topic in comparative HRM. Beyond cross-sectional research methodologies providing statistical snapshots of commonalities and differences, addressing this issue requires longitudinal analyses. Such analyses have been greatly helped through the data collection efforts of Cranet (www.cranet.org), which has provided the comparative HRM field with 40 years of widely representative country-comparative HRM data at five-year time intervals. This has encouraged studies in comparative HRM to address core questions about developments in HRM over time, thus providing insights into the convergencedivergence debate. The convergence argument is driven largely by the economic and general 
management literature (Uzzi, 1996; Drezner, 2001; Mayrhofer et al., 2011), which argues that the forces of globalisation will create management practices that become increasingly similar as a result of increased use around the world of very similar technologies and communication. This is reflected in the comparative HRM literature, where 'dominance effects' have been identified (Smith \& Meiksins, 1995; Pudelko \& Harzing, 2007), whereby those models that have been viewed as most successful have exemplary power in other communities, setting standards for the other countries. Another strand argues that regions are more important. The influence of the European Union on HRM has been profound, enforcing common legislation on contractual terms, on discrimination, on health and safety and on communication requirements, for example. Rather than global convergence, this strand of comparative HRM research suggests that over time we will witness regional convergence, with the regions becoming increasingly differentiated. However, other discussion within comparative HRM argues that we should not expect any convergence at all (Dunphy, 1987; Paik, Vance, \& Stage, 1996; Brewster, Mayrhofer, \& Farndale, 2018).

Generally speaking, both the cultural literature (López-Duarte, Vidal-Suárez, \& González-Díaz, 2016; Cooke, Veen, \& Wood, 2016) and the institutional literature (Meyer, 2015; Adams, Smart, \& Huff, 2017) argue that countries are distinctive and change only slowly, and that any change over time is path-dependent.

Contextualising HRM leads to at least three questions. First, can HRM in different contexts be conducted in a similar way or does it have to adapt to the respective circumstances? Behind this question lurks the discussion about best practice vs best fit, i.e., is there one best model of HRM, as is often assumed in US-based HR concepts, or is it necessary to take into account contextual specifics in order to achieve the best outcome? Second, what are the crucial forces leading to HRM-relevant contextual differences? The two major factors are culture and institutions. Third, 
how do similarities and differences between various contexts develop over time? Taking a temporal perspective, the issues of convergence, divergence or stasis arise, i.e., will the different contexts - most often countries - become more alike or more different, or stay relatively stable.

This chapter addresses these questions, first by exploring some of the key scholarly discussions in comparative HRM. These are the conceptual paradigms that underlie how the topic is understood; the issue of convergence and divergence; and the issue of the explanatory factors for the differences that are found. These conceptual differences provide a platform on which to explore some of the differences in the way that human resources are managed in different countries.

\section{The Concepts Behind Comparative HRM}

'When in Rome, do as the Romans do.' This applies to the ways HRM is conceptualised; the research traditions through which it is explored; and the way HRM is performed. In conceptual and research terms two different (ideal type) paradigms have been identified as the universalist and the contextual (Brewster, 1999). Early research referred to the notion of paradigms in the context of HRM (Delery \& Doty, 1996). In this chapter, the universalist and contextual paradigms will serve as good examples, building as they do on the significant US and northern European traditions.

The universalist paradigm, which tends to dominate in the USA is also widely used in other countries, is essentially a nomothetic social science approach: it uses (empirical) evidence to test generalisations of an abstract and law-like character. With reference to other areas in the social sciences, the universalist paradigm tends to result in convergence. This paradigm assumes that the purpose of the study of our area of the social sciences, HRM, and in particular SHRM (Younger, Smallwood, \& Ulrich, 2007; Delery \& Roumpi, 2017), is to improve the way that human resources 
are managed strategically within organisations, with little reference to contextual factors. In this view, the ultimate aim is to improve organisational performance (Huselid, 1995) or the customer experience (Ulrich, Brockbank \& Yeung, 1989), or to serve shareholders' interests (Becker \& Gerhart, 1996; Guest, 1997). Further, this debate assumes that that this objective will apply in all cultural and institutional contexts. The value of this paradigm is its simplicity, the merging of research around this shared view, and the clear relationship with the interest of practitionermanagers. The disadvantages lie in the ignoring of other potential focuses, the limitation on research objectives, and the ignoring of other levels of analysis and other stakeholders, such as communities (Beer, Boselie, \& Brewster, 2015; Guest, 2017). Arguably, there is greater coherence in the USA over what constitutes best practice in HRM: an evolving view around the notion of high-performance work systems (Becker \& Huselid, 2006). Pfeffer (1998) suggests the following seven principles as conditions of successful organisations:

\section{- Employment security}

- Selective hiring of new personnel

- Self-managed teams and decentralisation of decision-making as the basic principles of organisational design

- Comparatively high compensation contingent on organisational performance

- Extensive training

- Reduced status distinctions and barriers, including dress, language, office arrangements, and wage differences across levels

- Extensive sharing of financial and performance information throughout the organisation.

Similar to other studies in the field of SHRM, Pfeffer (1998) argues that organisational success is determined by the right set of HRM principles. Perhaps in a country like the USA, where there is widespread agreement that external factors, such as government regulation, trade unions, etc., 
should not be allowed to impact on business, there is some sense in developing a vision of HRM that takes as its scope simply the policies and practices of management.

By contrast, the contextual paradigm is idiographic; it seeks an overall understanding of what is contextually unique and why. In the field of comparative HRM, it aims to develop a better understanding of what varies between and within HRM in various contexts and what drives the differences (Paauwe \& Farndale, 2017). Often, the research methods used are inductive. Most of the literature highlighting the need for a more contextual paradigm research considers the link between HRM and firm performance to be secondary (see, e.g., Beer, Boselie, \& Brewster, 2015). It is assumed that HRM can apply to societies, governments or regions as well as to firms. At the level of the organisation the firm's objectives and strategy are not necessarily assumed to be good or bad for the organisation or for society: they have to be assessed in terms of their outcomes. Nor, in this paradigm, is there any assumption that the interests of everyone in the organisation will be the same, nor any expectation that an organisation will have a strategy that people within the organisation will support (see, e.g., Guest, 2017).

The contextual paradigm emphasises external factors as well as the management policies and practices within an organisation. Thus, it considers the importance of such factors as national culture, ownership structures, labour market structure, the role of the state and trade unions. The scope of HRM, it is argued, should reflect the reality of the role of many HRM specialists. For example, Haak-Saheem and Festing (2016) show empirically how institutional factors such as the role of the state shape HRM. This paradigm is widespread in European countries, and more widely - for example, in Australia and New Zealand. 
In summary, cultural and institutional views are fundamental to the comparative HRM approach. Comparative HRM uses these theories to understand differences between nations. Both approaches are relevant to understanding what is happening in HRM.

\section{Cultural and Institutional Factors Shaping HRM}

Since we know that there are differences in the way that countries understand and practise HRM, what are the reasons for these differences? Generally, speaking, there are two competing sets of explanators: the cultural and the institutional. If the differences in the meaning, objectives, practices and outcomes of HRM between nations are accepted, then the next step is to develop a better understanding of the reasons for, or the antecedents of, these differences. The cultural and institutional frameworks are broad categorisations and within each field there is a raft of competing and often incompatible theories. It is argued that different values and different relationships between people are clustered in countries and, inevitably, reflected in the way that people manage other people.

Fukuyama (1995) argues that organisations represent cultural communities of rational utilitymaximising individuals. Practices will vary with cultural context. Typically, these variations will reflect national boundaries, but this is by no means always the case. Thus, countries like Belgium or Spain contain communities speaking different languages, with different religions and different legislation, seeming, at least to the citizens there, sharply different in their approaches to life. Cultural groups in the Middle East and Africa were divided by the colonial map-makers and may have more in common with groups in countries across national borders than they do with other citizens of their own country (Wood et al., 2011; Haak-Saheem \& Festing, 2016). 
Whilst the cultural approach is an extremely broad one, it may be possible for a society to enhance its social capital, though it is not possible to develop social trust deliberately and systematically, or radically depart from established rules and norms (Fukuyama, 1995). Culture is viewed as being shared by individuals as a means of conferring meaning on, and adding sense to, social interactions. Even if the nature of that culture may be relatively fluid and subjective, it provides a persistent boundary to the life of individuals and clusters thereof.

Previous research found geographically based, usually national, differences in what is appropriate and not appropriate in particular contexts (Hofstede, 2001). These perceptions affect the way people in a country see and interpret the world. Schwartz (1999) and Sagiv and Schwartz (2007) emphasise the interrelation between cultural-level and individual-level values: each individual will be different but the aggregation of their approaches makes what is acceptable and desirable in one country different from what is acceptable or desirable in another. Since HRM is concerned with interactions between people at different hierarchical levels within an organisation, these cultural differences will inevitably be reflected in differences in the way people are managed.

In contrast to the cultural view, the institutional perspective argues that institutions within a society are the main factor influencing HRM (Vaiman \& Brewster, 2015). Social arrangements in a nation are always distinct and many of the institutions are likely to shape the social construction of an organisation. For example, the general and vocational education system, the way labour markets work and employment legislation will all impact on the way that HRM practices are applied (Björkman, Fey, \& Park, 2007). Thus, HRM has be considered as a function of the country's particular institutional arrangements (Haak-Saheem \& Festing, 2016). As with the cultural effects, there seems to be a kind of societal recipe that it is possible to go against, or ignore, but only at a cost. Most people, or most organisations, do not do so. 
The institutional view within the management literature is not new (Rosenzweig \& Singh, 1991). In particular, patterns of ownership vary (Brewster, 2007). Whilst public ownership has decreased to some extent in many European countries in recent years, large corporations in emerging economies - in the Gulf States, for example - are owned by the government (Haak-Saheem, Festing \& Darwish, 2017).

Whilst each stream of thought generally gives no more than a passing nod to the other view, it seems that neither an exclusively culturalist nor an exclusively institutional approach is helpful in the context of comparative HRM. Many of the cultural writers see institutions as key artefacts of culture that reflect deep underlying variations in the values across societies; many institutional writers include culture as one of the institutional elements explaining differences.

Both institutional and cultural accounts assume strong path dependence: neither institutions nor culture can be readily changed. This may easily lead to assumptions that countries characterised by poor economic performance are in some manner defective, and that others may be so irrevocably different as to preclude sustainable and peaceful long-term economic relations (McSweeney, 2012). Again, the fact that many national boundaries do not always coincide with ethnic variations has not prevented scholars from categorising cultural characteristics according to country (McSweeney, 2012).

However, even given these limitations, the institutional approach offers a wider range of explanations. For example, Wood et al. (2012) note that the new institutionalism is at least as multifaceted as the cultural literature and has similar problems of definition and measurement. However, they also note that there is a consistency to the notion that certain factors within society create a degree of isomorphism in organisations searching for legitimacy and resources (DiMaggio 
\& Powell, 1983) and that this in turn creates a certain path dependence in the directions that the society can take. As Hollingsworth (2006) suggests, it is likely that national institutional frameworks evolve in a non-linear fashion that combines continuity with change. Vaiman and Brewster (2015) argue that companies have considerable, if not unlimited, scope to manage cultural differences, but fewer opportunities to ignore educational systems, labour markets, government regulations, legislation and other institutional aspects of a society.

Overall, the interests of shareholders play a prominent role in this literature (Jackson \& Deeg, 2008) and they have also been given prominence in the comparative capitalisms literature, although the latter sees societal restraints on shareholder rights as being potentially beneficial, rather than pathological. Hence, comparative capitalisms theory makes a distinction between the liberal market economies (LMEs) of the Anglo-Saxon world and the coordinated market economies (CMEs) of the Rhineland, Scandinavia and Japan (Hall \& Soskice, 2001). For LMEs, shareholder value is pre-eminent, contractual relationships tend to be short-term and are trumped by the need for competition, and the government is expected to play only a facilitating role (Wilkinson \& Wood, 2017). In CMEs, relationships between organisations are less competitive and adversarial, and the government accepts more responsibility for the way business is conducted (which is meant to be in the interests of a wider group of stakeholders than just the owners of the business) and for the way people at work are treated (Hall \& Soskice, 2001; Wood \& Lane, 2012). According to Hall and Soskice (2001), the complementarity of institutional factors at either end of the scale allows for successful economies, but between the two extremes, societies will find it difficult to be economically successful and will be pressured to move in one direction or the other.

These dichotomous models have been found wanting by other authors (Whitley, 1999; Amable, 2003), who have argued that the mature economies cannot be readily divided into two archetypes, 
and that countries that fall in neither category will not necessarily converge towards one or the other. Amable (2003) divides the CME category up between the developed East Asian economies, Scandinavia, the Mediterranean economies, and the Rhineland economies.

The models that we have so far tend to be very Eurocentric, meaning that they ignore most of the world (Jackson \& Deeg, 2008). Recently there have been attempts to explore national business systems in the Arab Gulf States (Haak-Saheem \& Festing, 2016) or Africa, labelled as segmented business systems (Wood \& Frynas, 2006).

Despite the wealth of literature on institutionalism, it has remained difficult to explain internal diversity of market economies (Walker, Brewster, \& Wood, 2014). The early literature on comparative capitalism tended to take a static view, since societies were conceived of as consisting of reinforcing complementarities, which makes it difficult to explain systemic change (Streeck \& Thelen, 2005). Some of the criticisms of these comparative capitalisms theories have also come from people concerned about the mismatch between the theoretical attempt to explain firm-level behaviour and the fact that much of the evidence adduced is drawn from broad trends in labour markets, legalisation, limited panels of case studies and/or broad macroeconomic indicators (Wood et al., 2011). In other words, although the literature on comparative capitalism makes broad assumptions as to how work and employment relations vary from setting to setting, there is very little on what really goes on inside the firm (Wood et al., 2011).

\section{Convergence and Divergence in HRM}

The convergence-divergence debate has been an ongoing issue in international management (Fenton-O'Creevy \& Gooderham, 2003) and presents the argument that the patterns of organisational and institutional behaviours within industrial societies have been 'converging' or 
becoming more similar. When researchers began first to study the management of organisations in different countries, the belief was that management principles would hold universally (Gooderham \& Brewster, 2003). The convergence-divergence debate highlights the arguments that HRM within organisations will become increasingly similar due to firms having structures that are free from cultural influences and are more affected by more tangible influences such as industry, size and technology, with globalisation freeing MNEs from the influence of national institutions; this has renewed interest in the convergence hypothesis (Farndale et al., 2017).

Early management researchers assumed that organisational practices would converge towards the most efficient model, which would therefore, they argued, be the US model (Smith \& Meiksins, 1995; Pudelko, 2005). More recently, the convergence thesis has received support from transaction cost economics, which argues that there always exists a best solution to organising labour (Williamson, 1985). Benchmarking practices in organisations focus on the diffusion of best practice (Wright \& Brewster, 2003). They have doubtless contributed to shaping similar forms of organisation across countries as well as similar curricula in business education.

Most of these views nowadays centre on convergence towards a US model - the model of the most powerful country in the world (Smith \& Meiksins, 1995). Previously, the dominant model was that of Japan and it may, in the not-too-distant future, be that of China. However, at present, one theoretical possibility is that as policies of market deregulation and state de-control are spreading from the USA to Europe and elsewhere, firms everywhere will move towards North American HRM.

Another possibility is that different regional models of HRM may be created. The increasing economic and political integration of the European Union (EU) countries, for example, may cause 
a convergence, within Europe, towards a distinct European model of HRM. In Europe, 27 countries, currently, are engaged in a historically unique collaboration: they have agreed to subordinate national legislative decision-making to European-level legislation. These developments have indirect effects upon the way people are managed as a result of political and economic integration and direct effects through the EU's adoption of a distinct social sphere of activity. The advent of the EU, providing institutional arrangements at the supra-national level, may, through such developments, support an institutional branch of convergence theory (Gooderham \& Brewster, 2003).

There is also a third theoretical possibility: that organisations are so locked into their respective national institutional settings that no common model is likely to emerge for the foreseeable future. Since HRM systems reflect national institutional contexts and cultures, which do not respond readily to the imperatives of technology or the market, each country will continue to be distinctive (DiMaggio \& Powell, 1983). The literature often refers to divergence theories, but what is usually meant is 'non-convergence': no one is arguing that countries are becoming even more dissimilar - just that they remain distinctive in the way that they manage their HRM. Managers in each country operate within a specific national institutional context and have a shared set of cultural assumptions. Neither institutions nor cultures change quickly, and they rarely do so in ways that are the same as in other countries. It follows that managers and workers within any one country behave differently from managers in other countries. More importantly, change is path-dependent. In other words, even when change does occur it can be understood only in relation to the specific social context in which it occurs. Even superficially universal principles (profit or efficiency) may be interpreted differently in different countries (Hofstede, 2001). 
Attempts have been made to develop a more nuanced theory of convergence (Brewster, Mayrhofer, \& Morley, 2004; Farndale et al., 2017). These authors develop a distinction between directional convergence (whether countries share the same trend) and final convergence (whether they are becoming more alike) and also analyse the extent of convergence, arguing that you can have more or less rather than just all or none. In the literature, evidence of similarity in HRM between countries, or similar trends, has sometimes been taken as evidence of convergence: but convergence can only be shown over time - and if countries start, as they do, from different positions, even similar trends (directional convergence) may not lead to increasing similarity between countries.

The evidence from the Cranet surveys shows that in Europe many aspects of HRM show directional convergence: there are similar trends. This is not always the case: the ratio of HRM specialists to the rest of the organisation, or the size of the HRM department, varies considerably with, mainly, country, but also with the size of the organisation (Brewster, 2007), but does not show any clear directional trends. Neither does training and development, which is given high priority in many countries but seems to remain the first area for cuts when finances become tight. Despite the similarities in trends, however, there is very little evidence of countries becoming more alike in the way that they manage their human resources. The evidence is summarised as follows: from a directional convergence point of view, there seems to be a positive indication of convergence. However, when one looks at the question from a final convergence point of view, the answer is no longer a clear positive. None of the HRM practices converge (Brewster, Mayrhofer, \& Morley, 2004).

Let us examine some examples of national differences: we look at communication, flexible 
working patterns, and the nature of the HRM department.

Communication with their workers is crucial to all organisations. Arguably, at least at the organisational level, effective communication is key to effective HRM. Yet communication varies by country. The USA tends to emphasise individual communication as the key, whilst Europeans tend to stress collective communication. Because of the dominance of the US model of HRM, much of the literature associates HRM with the individualisation of communication and a move away from, or even antagonism towards, communication and consultation that is collectively or, particularly, trade union based (Brewster, 2004). But trade unionism remains widespread and important and, in Europe and elsewhere in the world, there are extensive, legally backed, systems of employee communication. These arrangements tend to supplement rather than supplant the union position (Brewster et al., 2007).

In fact, the evidence seems to show increases in all forms of communication: through representative bodies (trade unions or works councils), and through direct verbal and written communication (Brewster et al., 2007). Trade union membership remains very high in some countries (in many Nordic countries, for example, most of the workforce, including the managers, are members of trade unions); but it is much lower in some other countries and there are many where it is effectively non-existent. The increases in direct communication to employees can be explained by the development of technology: word processors and mail-merge systems allow the sending of 'individual' letters to all employees.

When upward communication is examined, the two most common means, by a considerable margin, are through immediate line management and through the trade union or works council channel. There are clear differences between countries in regard of communication design and 
processes. Extensive communication, both up and down seems to work: it increases most in the countries where most communication goes on (Mayrhofer, Brewster, \& Morley, 2000).

Everywhere, access to financial and strategic information is clearly hierarchical. The higher your position in the organisation, the more likely you are to be regularly briefed about the financial performance of the organisation or about its strategic plans. There are noticeable differences in average 'slopes' in the distribution of this information: lower-level employees in the Nordic countries, for example, receive considerably more information than those elsewhere.

Flexibility in labour patterns is a much-discussed topic in HRM, variously referred to as 'flexibility', 'atypical working', 'vulnerable work' or 'contingent working'. Arguably, all of these terms bring with them their own metaphorical baggage. Research conducted by the Cranet network, comparing organisations at the national level across Europe (Tregaskis \& Brewster, 2006), is consistent with the national labour market statistics, and workplace-level data (Kersley et al., 2006) in showing extensive use of flexible working in most developed societies, but it takes different forms in each. Temporary employment is more widespread in Europe than in the USA. Part-time working is high in Denmark and short-term contracts are common in Spain. Japan has a lot of both. Differences in the kind and extent of flexible working correlate with the different institutional environments of countries (Ruiz-Quintanilla \& Claes, 1996; Tregaskis \& Brewster, 2006). Similarly, analyses of the extent of flexible working in Japan need to take into account the Japanese practice of restricting employment for women of above 'marriageable' age. Overall, although the trends are similar, there are still very different situations, assumptions and practices occurring in the different countries. 
However, flexible working practices are growing in both extent and coverage almost everywhere (directional convergence). This is so in nearly all countries in Europe, in Japan and Australasia, in all parts of the economy, in organisations of all sizes, and whatever the form or origin of ownership. 'Atypical' work patterns or contracts, such as temporary, casual, fixed-term, home-based and annual hours contracts, are spreading, despite differing legal, cultural and labour traditions. Currently only around half of the European working population has standard (permanent, full-time, etc.) employment contracts. This has been exacerbated recently by the creation and rapid growth of the platform or 'gig' economy, where people work for (but are not employed by - they work as 'self-employed contractors') a computer-based app, so that there is no longer any personal relationship with the organisation they are working for (Brewster \& Holland, 2019).

All this will have extensive effects on HRM but also, beyond the world of work, in areas such as finance and the housing market (mortgages and bank loans are often dependent on 'regular' employment); tax (with people working but not paying income taxes - a major source of revenue for many countries); and demands on government resources.

The role of the HRM function, unsurprisingly, given the differences we have noted, also varies substantially across countries. Since human resources and the knowledge and skills they incorporate are difficult to replicate, they offer organisations the opportunity of obtaining sustained competitive advantage. So we might anticipate that the influence of the human resource function on corporate decision-making increases over time. We examine the position of HRM in relation to the decision-makers within the organisation; the role of line management; and the extent of outsourcing of HRM. 
In countries such as France, Spain, Sweden and Japan, over the years $70 \%-80 \%$ of organisations of over 200 employees have consistently had senior HRM specialists on the company board (or its equivalent); in the Central and Eastern European countries the figures are much lower. Most European countries show that the HRM department is represented at the top decision-making level in slightly fewer than half of the organisations. When it becomes a question - perhaps the key question - of HRM influence on corporate strategy, there is more uniformity: in most countries personnel departments are involved in strategy formulation from the outset in around half of the organisations (Farndale et al., 2017).

The role of line managers in strategic (and indeed in operational) HRM has been seen as a touchstone of HRM (Darwish et al., 2017). The argument is that organisations should give more HRM responsibility to line managers who are, after all, the ones who know their people best. In fact, the trend is the other way, with most organisations centralising their HRM policies in the HRM department (Brewster, Brookes, \& Gollan, 2015). Again, this varies by country and in this case largely by education standards. Countries like Finland and Denmark, with all their welleducated managers and workforces, give more responsibility to their line managers, and countries like the USA and the UK, much less. These differences, too, persist over time.

\section{Summary}

Comparative HRM matters because, in each country, organisations manage their people differently. The way people are managed in the UAE is different from the way they are managed in Japan, which is different from the way they are managed in the USA - and so on. And although there are common trends, and there is certainly common rhetoric, there is no sign that these differences are going to decline. The best way to manage people in your country is probably very 
similar to the way most other people are managed; and unless you are in a very similar country to the USA, the adaption of practices and policies are likely to be not only problematic but, probably, ineffective. It is important to understand the way things are done in your own country and to work from there. What is the culture of your country? What are the institutional bases (the wealth, the coherence, the legislation (and how strictly it is enforced), the education system, the labour market, etc.) of your country? Once you understand these and the typical HRM practices of your country, you will be in a much better position to decide how to improve HRM within the context that matters to you.

\section{References}

Adams, R. J., Smart, P., \& Huff, A. S. (2017). Shades of grey: Guidelines for working with the grey literature in systematic reviews for management and organizational studies. International Journal of Management Reviews, 19, 4, 432-454.

Amable, B. (2003). The diversity of modern capitalism. Oxford University Press on Demand.

Aycan, Z. (2005). The interplay between cultural and institutional/structural contingencies in human resource management practices. International Journal of Human Resource Management, $16,7,1083-1119$.

Bamberger, P. (2008). Beyond contextualization: Using context theories to narrow the micromacro gap in management research. Academy of Management Journal, 51, 5, 839-846.

Becker, B. E., \& Huselid, M. A. (2006). Strategic human resources management: Where do we go from here? Journal of Management, 32, 6, 898-925.

Becker, B., \& Gerhart, B. (1996). The impact of human resource management on organizational performance: Progress and prospects. Academy of Management Journal, 39, 4, 779-801. 
Beer, M., Boselie, P., \& Brewster, C. (2015). Back to the future: Implications for the field of HRM of the multistakeholder perspective proposed 30 years ago. Human Resource Management, 54, 3, 427-438.

Björkman, I., Fey, C. F., \& Park, H. J. (2007). Institutional theory and MNC subsidiary HRM practices: Evidence from a three-country study. Journal of International Business Studies, 38, 3, $430-446$.

Brewster, C. (1999) 'Strategic Human Resource Management: The Value of Different Paradigms', Management International Review, Special Issue, 45-64.

Brewster, C. (2004). European perspectives on human resource management. Human Resource Management Review, 14, 4, 365-382.

Brewster, C. (2007). A European perspective on HRM. European Journal of International Management, 1, 3, 239-259.

Brewster, C., Brookes, M., \& Gollan, P. J. (2015). The institutional antecedents of the assignment of HRM responsibilities to line managers. Human Resource Management, 54, 4, 577-597.

Brewster, C., \& Holland, P. (2019). Work 'or' employment in the $21^{\text {st }}$ century? In A. Wilkinson \& M. Barry. The research agenda for the future of work. Cheltenham: Edward Elgar.

Brewster, C., Mayrhofer, W., \& Farndale, E. (eds) (2018). Handbook of research on comparative human resource management. Chichester: Edward Elgar Publishing.

Brewster, C., Mayrhofer, W., \& Morley, M. (eds) (2004). Human resource management in Europe: Evidence of convergence? London: Routledge. 
Brewster, C., Wood, G., \& Brookes, M. (2008). Similarity, isomorphism or duality? Recent survey evidence on the human resource management policies of multinational corporations. British Journal of Management, 19, 4, 320-342.

Brewster, C., Wood., G., Croucher, C., \& Brookes, M. (2007). Are works councils and joint consultative committees a threat to trade unions? A comparative analysis. Economic and Industrial Democracy, 28, 1, 53-81.

Cooke, F. L. (2018). Concepts, contexts, and mindsets: Putting human resource management research in perspectives. Human Resource Management Journal, 28, 1, 1-13.

Cooke, F. L., Veen, A., \& Wood, G. (2017). What do we know about cross-country comparative studies in HRM? A critical review of literature in the period of 2000-2014. International Journal of Human Resource Management, 28, 1, 196-233.

Darwish, T., Mohamed, A. F., Wood, G., Singh, S., \& Fleming, J. (2017). Can HRM alleviate the negative effects of the resource curse on firms? Evidence from Brunei. Personnel Review, 46, 8, 1931-1947.

Delery, J. E., \& Doty, D. H. (1996). Modes of theorizing in strategic human resource management: Tests of universalistic, contingency, and configurational performance predictions. Academy of Management Journal, 394, 802-835.

Delery, J. E., \& Roumpi, D. (2017). Strategic human resource management, human capital and competitive advantage: Is the field going in circles? Human Resource Management Journal, 27, $1,1-21$.

DiMaggio, P. J., \& Powell, W. W. (1983). The iron cage revisited: Institutional isomorphism and collective rationality in organizational fields. American Sociological Review, 48, 147-160. 
Drezner, D. W. (2001). Globalization and policy convergence. International Studies Review, 3, 1, $53-78$.

Dunphy, D. (1987). Convergence/divergence: A temporal review of the Japanese enterprise and its management. Academy of Management Review, 12, 3, 445-459.

Farndale, E., Brewster, C., Ligthart, P., \& Poutsma, E. (2017). The effects of market economy type and foreign MNE subsidiaries on the convergence and divergence of HRM. Journal of International Business Studies, 48, 9, 1065-1086.

Fenton-O'Creevy, M., \& Gooderham, P. N. (2003). International management of human resources, $17,1,2-5$.

Fukuyama, F. (1995). Social capital and the global economy. Foreign Affairs, 74, 89.

Gooderham, P. N., \& Brewster, C. (2003). Convergence, stasis or divergence? Personnel Management in Europe, Beta, 17, 1, 6-18.

Guest, D. E. (1997). Human resource management and performance: A review and research agenda. International Journal of Human Resource Management, 8, 3, 263-276.

Guest, D. E. (2017). Human resource management and employee well-being: Towards a new analytic framework. Human Resource Management Journal, 27, 1, 22-38.

Haak-Saheem, W., \& Festing, M. (2016). Human resource management - a national business system perspective. International Journal of Human Resource Management, 1-28.

Haak-Saheem, W., Festing, M., \& Darwish, T. K. (2017). International human resource management in the Arab Gulf States - an institutional perspective. International Journal of Human Resource Management, 28, 18, 2684-2712. 
Hall, P. A., \& Soskice, D. (2001). An introduction to varieties of capitalism. In P. Hall, \& D. Soskice (eds), Varieties of capitalism: The institutional foundations of competitive advantage, 168. Oxford: Oxford University Press.

Hamel, G., \& Prahalad, C. K. (1985). Do you really have a global strategy? International Executive, 27, 3, 13-14.

Hofstede, G. (2001) Culture's Consequences, 2nd Edition, Thousand Oaks, London.

Hollingsworth, J. R. (2006). A path-dependent perspective on institutional and organizational factors shaping major scientific discoveries. Innovation, Science, and Institutional Change, 423442.

Huselid, M. A. (1995). The impact of human resource management practices on turnover, productivity, and corporate financial performance. Academy of Management Journal, 38, 3, 635672.

Jackson, G., \& Deeg, R. (2008). Comparing capitalisms: Understanding institutional diversity and its implications for international business. Journal of International Business Studies, 39, 4, 540561.

Kersley, B., Alpin, C., Forth, J., Bryson, A., Bewley, H., Dix, G., \& Oxenbridge, S. (2006). Inside the workplace: Findings from the 2004 Workplace Employment Relations Survey. London: Routledge.

López-Duarte, C., Vidal-Suárez, M. M., \& González-Díaz, B. (2016). International business and national culture: A literature review and research agenda. International Journal of Management Reviews, 18, 4, 397-416. 
Mayrhofer, W., Brewster, C., \& Morley, M. (2000). Communication, consultation and the HRM debate. In C. Brewster, W. Mayrhofer, \& M. Morley (eds), New challenges for European human resource management. Basingstoke: Macmillan.

Mayrhofer, W., Brewster, C., Morley, M. J., \& Ledolter, J. (2011). Hearing a different drummer? Convergence of human resource management in Europe - a longitudinal analysis. Human Resource Management Review, 21, 1, 50-67.

McSweeney B (2012) Constitutive contexts: the myths of common cultural values. In: Wood G and Demirbag M (eds) Handbook Of Institutional Approaches To International Business, Cheltenham: Edward Elgar 142-172.

Meyer, K. E. (2015). Context in management research in emerging economies. Management and Organization Review, 11, 3, 369-377.

Paauwe, J., \& Farndale, E. (2017). Strategy, HRM, and performance: A contextual approach. Oxford: Oxford University Press.

Paik, Y., Vance, C. M., \& Stage, H. D. (1996). The extent of divergence in human resource practice across three Chinese national cultures: Hong Kong, Taiwan and Singapore. Human Resource Management Journal, 6, 2, 20-31.

Pfeffer, J. (1998). Seven practices of successful organizations. California Management Review, 40, 2, 96-124.

Pudelko, M. (2005). Cross-national learning from best practice and the convergence-divergence debate in HRM. International Journal of Human Resource Management, 16, 11, 2045-2074.

Pudelko, M., \& Harzing, A. W. (2007). Country-of-origin, localization, or dominance effect? An empirical investigation of HRM practices in foreign subsidiaries. Human Resource Management: 
Published in cooperation with the School of Business Administration, the University of Michigan and in alliance with the Society of Human Resources Management, 46, 4, 535-559.

Rosenzweig, P. M., \& Singh, J. V. (1991). Organizational environments and the multinational enterprise. Academy of Management Review, 16, 2, 340-361.

Ruiz-Quintanilla, S. A., \& Claes, R. (1996). Determinants of underemployment of young adults: A multicountry study. Industrial and Labour Relations Review, 49, 3, 424-439.

Sagiv, L., \& Schwartz, S. H. (2007). Cultural values in organisations: Insights for Europe. European Journal of International Management, 1, 3, 176-190.

Schwartz, S. H. (1999). A theory of cultural values and some implications for work. Applied Psychology, 48, 1, 23-47.

Smith, C., \& Meiksins, P. (1995). System, society and dominance effects in cross-national organisational analysis. Work, Employment and Society, 9, 2, 241-267.

Streeck, W., \& Thelen, K. A. (eds) (2005). Beyond continuity: Institutional change in advanced political economies. Oxford: Oxford University Press.

Tregaskis, O., \& Brewster, C. (2006) Converging or diverging? A comparative analysis of trends in contingent employment practice in Europe over a decade. Journal of International Business Studies, 37, 111-126.

Ulrich, D., Brockbank, W., \& Yeung, A. (1989). Beyond belief: A benchmark for human resources. Human Resource Management, 28, 3, 311-335.

Uzzi, B. (1996). The sources and consequences of embeddedness for the economic performance of organizations: The network effect. American Sociological Review, 61, 4, 674-698. 
Vaiman, V., \& Brewster, C. (2015). How far do cultural differences explain the differences between nations? Implications for HRM. International Journal of Human Resource Management, $26,2,151-164$.

Walker, J. T., Brewster, C., \& Wood, G. (2014). Diversity between and within varieties of capitalism: Transnational survey evidence. Industrial and Corporate Change, 23, 2, 493-533.

Whitley, R. (1999). Divergent capitalisms: The social structuring and change of business systems. Oxford: Oxford University Press.

Wilkinson, A., \& Wood, G. (2017). Global trends and crises, comparative capitalism and HRM. International Journal of Human Resource Management, 27, 18, 2503-2518.

Williamson, O. (1985) The Economic Institutions of Capitalism, New York: Free Press.

Wood, G., \& Frynas, J. G. (2005). The institutional basis of economic failure: Anatomy of the segmented business system. Socio-Economic Review, 4, 2, 239-277.

Wood, G., \& Lane, C. (eds) (2011). Capitalist diversity and diversity within capitalism (vol. 151). London: Routledge.

Wood, G., Dibben, P., Stride, C., \& Webster, E. (2011). HRM in Mozambique: Homogenization, path dependence or segmented business system? Journal of World Business, 46, 1, 31-41.

Wood, G., Psychogios, A., Szamosi, L. T., \& Collings, D. G. (2012). Institutional approaches to comparative HRM. In C. Brewster \& W. Mayrhofer (eds), Handbook of research on comparative human resource management, 27-50. Cheltenham, England: Edward Elgar.

Younger, J., Smallwood, N., \& Ulrich, D. (2007). Developing your organization's brand as a talent developer. People and Strategy, 30, 2, 21. 